\title{
PROMISSORY NOTE AS PAYMENT SECURITY INSTRUMENT IN THE REPUBLIC OF CROATIA *
}

\author{
Branimir Marković, Professor \\ Branko Matić, Professor \\ Domagoj Karačić, Assistant \\ Faculty of Economics in Osijek
}

\section{SUMMARY}

In the modern world, a legal framework has been set up and a market regulator has been defined so that payment as a relation between the debtor and creditor can not be put in question regarding the realization of their integral rights. Countries in transition, including Croatia (the Republic of Croatia), are still trying to define not only the shortterm, but also the long-term regulators that would clarify all open questions both in the economic and in the legal segment. Promissory note as the payment security instrument has in practice become operative only through a consistent use of Distraint law. A theoretical and an implementation mechanism merge into one functional mechanism, on the basis of which it can be said that in this segment the Republic of Croatia has truly overcome the transitional barriers.

Key words: promissory note, collection of claims, payment insurance, blank promissory notes, Distraint procedure, Distraint law.

\subsection{INTRODUCTION}

The present-day economic situation in the Republic of Croatia has been conditioned by numerous difficulties that arise in the billing system between business entities within the economic system. Because of their inability to collect claims, numerous companies acting as creditors must consider different forms of protection of their demands through additional elements of insurance of payment, because the rising trend of financial insolvency that is especially present among the small and medium businesses in the Republic of Croatia.

Standard payment security instruments that appear in the creditors' claims charging process are: security right on movables and rights, blank bills of exchange and no-

* The presented results are the outcome of the following projects: 1. Bank System in the Financing of Polycentric Development (No. 010-0102290-1284), 2. Financing of Local and Regional SelfGovernment (No. 010-0102290-2446) and 3. Restructuring of Companies in Business Distress (No. 010-0102290-2292), conducted with the support of the Ministry of Science, Education and Sports of the Republic of Croatia 
negotiable checks, solidary debtors and guarantors, cessions or assignations, declaration about the consent for the confiscation of salary, agreement declaration about the payment of immediate liabilities from all accounts that the business entity has in the bank, the agreement authorization for the bearing of order of payment and the common and blank promissory notes. Every insurance instrument has, depending on the form and manner of use, certain specific characteristics, in other words, it is either presented as a payment security instrument, or has characteristics of an agreement, or may be determined as a security. As one of the elements of payment security instruments, there is also the promissory note (note of hand and blank note). Promissory notes as means of insurance also have important role in the domain of protection of the insurance of creditor's rights in the collection of outstanding debts, because the process of collection of outstanding debts is resolved in out-of-court procedure, which significantly reduces the collection period, but also reduces all sorts of costs that may emerge (today the Distraint law is more efficient compared to ordinary litigation). This payment security instrument has been introduced as a formal legal procedure that should provide faster, simpler and more efficient reaction to the processes of realization of creditors' claims.

\subsection{CHARACTERISTICS OF THE PROMISSORY NOTE}

Promissory note is defined as the classic form of written document issued by the debtor, carrying his signature, the stated object of confiscation and the time by which the note is due, and it gives the creditor the right to charge claims, by way of confiscating all debtor's accounts that he has with legal persons dealing with payment transactions, and by transferring the money from these accounts directly to the creditor in a way determined by this declaration that must be verified by a notary public.

The initial definition explaining the concept of promissory note is the one in the Distraint Law, adopted and published in the Official Gazette (Narodne novine - NN) no. 57/96, Art. 183, section 1 . Promissory note is not specifically mentioned as a term, but in this case the concept of "seizure of account with the consent of the debtor" is defined, which is essentially similar to the actual present-day definition of promissory note. It is said that:

The debtor can give his consent through declaration verified by a notary public that his account with a bank or other legal person dealing with payment transactions may be seized for the purpose of payment of creditor's claims and that the money from this account, according to his declaration included in this document, are to be directly transferred from that account to the creditor

Promissory note as a payment security instrument differs from other payment instruments. It provides the creditor with a better position and a more efficient realization 
of his rights on claims, partly also because the implementation of the Distraint Law has started functioning at last. What makes the instrument of promissory note specific is that it has a multiple nature:

1.) promissory note as security - it is a known fact that, unlike the promissory note, securities have no classic document form; in this context it can be concluded that the promissory note belongs to traditional securities.

2.) formality of the promissory note - as a strictly formal legal instrument, it is regulated by law.

3.) functional determination of the promissory note - irrefutably enables the creditor to fulfill his rights.

4.) abstractness of the promissory note - in the promissory note the real nature of the business and legal relation between the creditor and the debtor is not specified.

5.) promissory note as Distraint proposal - the creditor will charge his claim coercively, there is no need for long-lasting court proceedings.

\subsection{KINDS OF PROMISSORY NOTES}

There are two kinds of promissory notes which are identical in their content, whereby blank promissory notes are defined by the Supplementary Law on the Distraint Law Art. 183, section 1, published in NN no. 29/99, while the common promissory note has not been defined by any legal act and it need not be issued on a prescribed form, so that in practice, the term and the form regulated by law are more frequently used.

It should be pointed out that the form of a common promissory may be written by hand and composed by the debtor himself, whereas a blank promissory note may be issued only on the form prescribed by the Book of Regulations ${ }^{2}$, and the form may be obtained in free sale. In practice, common promissory note is most often used by the debtor who is a physical person, because physical persons as debtors are not allowed to issue blank promissory notes.

Both kinds of promissory notes are similar in content, because, in the end, they must have the effect of a valid writ of execution, they must contain the designation of the acceptor's account and they must contain all required elements in order to be legally valid in the framework of fulfilling the institute as the instrument of insurance.

Blank promissory note differs from the common promissory note in so far that in the blank promissory note, when it is issued, neither the person of the creditor, nor the

\footnotetext{
${ }^{2}$ Pravilnik o obliku i sadržaju bjanko zadužnice (Book of Regulations on the Form and Content of a Blank Promissory
} Note), NN no. $107 / 99$, no. $135 / 99$, no. $136 / 05$. 
amount of claims owed by the debtor need be stated. Such principle can have undesired consequences for the issuer of the promissory note, so that the Law on Corporations (v. NN no. 111/93 to $118 / 03$ ) has more clearly regulated that only tradespersons may issue blank promissory notes. Since the Distraint Law has not clearly specified which tradespersons these are in the legal sense, we can assume that the blank promissory notes can be issued by companies and sole proprietors. However, following the regulations and the implementation of the Distraint Law in the economic system of collecting claims, the same may also apply for a craftsman, which means that a craftsman who is a debtor is permitted to issue a blank promissory note.

Unlike the common promissory note, the blank promissory note contains a specified amount of claims that may be issued only up to the highest prescribed rate, which is stated in Remark no.1 on the pattern of a blank promissory note, where the following amounts of money are listed: up to 5,000.00 HRK, up to $10,000.00 \mathrm{HRK}$, up to 50,000.00 HRK, up to $100,000.00 \mathrm{HRK}$, up to $500,000.00 \mathrm{HRK}$ or up to $1,000,000.00 \mathrm{HRK}$.

\subsection{Common Promissory Note}

Common promissory note is defined by Art. 183, section 1 of the Distraint Law as document bearing the debtor's signature and verified by the notary public, a document by which the debtor gives his consent regarding the confiscation of one or more debtor's accounts, through which the claims of a determined creditor are collected and settled. According to Art. 183, section 2 of the Distraint Law it is possible to subsequently register a guarantor payer on the promissory note or in additional documents accompanying the promissory. The guarantor payer gives the identical written declaration consistent with the declaration of the first debtor, where the guarantor answers to the creditor for the whole commitment solidarily with the debtor.

If the written document does not contain the expression "common" but only "promissory note", one must keep in mind that it is still a common promissory note, because blank promissory note has been defined as a legitimate institute.

In respect to the fact that the common promissory note may be composed by the debtor himself, the debtor must take into account that the common promissory note contains the following elements:

1. description of debtor's account(s) to be confiscated - specified or all accounts that the debtor has in a commercial bank or in the Financial Agency (FINA).

2. description of the monetary claims that are being confiscated - it is very important 
to specify the correct amount of claims, the interests (if they have been determined between the debtor and the creditor) and maturity of the claims, in order to avoid possible misunderstandings relating to the date of activation of the promissory note.

3. description of the debtor's consent - declaration in the form: I give my consent... or I agree...

4. data about the issuer - first name and family name of the debtor, his JMBG (Unique Master Citizen Number), his residence or if the debtor is a company, the company's headquarters and its MB (Master Number)

5. data about the authorized person - data which are filled in identically as for the issuer

6. description of the place and date of issuing of the common promissory note - the usual integral part of every legal document.

\subsection{Blank Promissory Note}

Blank promissory note has been regulated and defined by Art. 183a sections 1, 2, 3 and 4. Blank promissory note is defined as the document bearing the verified signature of the debtor tradesperson, by which he gives the consent for the payment of claims, but the amount of which may be subsequently added to the description of monetary claims which are being confiscated from the account held by the debtor in a merchant bank or FINA. According to the debtor's verified declaration, assets can be transferred to the creditor that has been determined in the document or that can be subsequently specified.

In contracting a blank promissory note as a legal relation by which conditions of collecting claims are additionally insured, the participants should precisely determine which claim is insured by means of a blank promissory note and under which conditions, because this will contribute to greater legal security and it will directly reduce the possibility of objection in the event of misunderstanding. It often happens in practice that the same participants engage in more than one business activities, and that claims are insured by means of blank promissory notes. In such cases, promissory notes can be marked with ordinal numbers for the purpose of simpler tracking and registering of new circumstances.

Notary public has the duty to verify the debtor's signature, and check it upon the insight into the identity card and into the excerpt from the court register of the legal person's or society's representative i.e. of the person authorized for representation and issuing of blank promissory notes. Blank promissory notes are composed and issued in duplicate; the creditor takes the original of the blank promissory note, whereas the copy remains with the notary public. The original and verified blank promissory held by the creditor bears the original signature of the debtor, and serves as the security and cover for the realization of the right to collect claims. 
The blank promissory note does not contain any description of the business activity on which the insurance of the creditor's claim is based, but the establishment of the existence of a claim and of its amount is based on the declaration of authority, according to which the declaration on the promissory note and receipts from commercial banks or FINA are the only valid and admissible instruments of insurance of claims.

\subsubsection{Contents of a Valid Blank Promissory Note}

1. denotation of one of the denominations, i.e. the highest sum to which the promissory note may be charged (according to note no. 1 at the bottom of the $1^{\text {st }}$ page of the form).

2. obligatory registration of the data about the debtor - name of the firm, its headquarters and $\mathrm{MB}$

3. prior to submitting the promissory note for payment, the creditor will write down the specific amount of his claim (it must be one of the denominations according to section 1 of the contents) and the maturity date of the claim.

4. authorization by which the debtor gives his consent for seizure of the accounts that he has by with the legal persons dealing with transaction payment operations.

5. it is necessary to specify data about the creditor, which can be done subsequently by the creditor prior to bearing the promissory note for payment, or by the debtor in the course of issuing of the promissory note.

6. the issuer, or the representative of the issuer, must sign the promissory note and bring the signed promissory note to the notary public for verification.

\subsection{PAYMENT OF THE PROMISSORY NOTE}

There is regular collection of payment of the promissory note and payment of the promissory note through legal proceeding. When the debtor who issued the promissory note does not voluntarily pay the full or partial amount of the creditor's claims, the creditor who satisfies formal conditions may submit a claim to the commercial bank or FINA and thus realize his rights that have been regulated with the consent of the debtor in the verified promissory note. If the assets are not found on the accounts that have been consensually given to the creditor for the payment of claims, or if they are not sufficient to settle the claim in full, then a problem arises, and in that case the payment of the promissory note can and must be activated through court procedure. 


\subsection{Regular Payment}

The regular payment procedure takes place when the debtor does not voluntarily fulfill his commitment upon the maturity of claim, and in that case the creditor who satisfies the formal conditions according to the promissory note is authorized to activate the promissory note for payment to the legal person dealing with payment transactions (commercial banks or FINA). If the maturity of claims has been specified in the promissory note, the creditor must deliver the promissory note before the maturity date; if the maturity of claim has not been specified, the maturity date will be the day or date when the creditor has delivered the promissory note to the commercial bank or FINA.

The Distraint Law explicitly prescribes that the promissory notes must be delivered in the reception office of the legal person where the payment transactions take place, via registered mail with return receipt or through the notary public.

Commercial bank or FINA as the institutions dealing with payment transactions have a supervisory function in the framework of proving the validity of the promissory note through some technical details, and upon the full payment of the promissory note they are obliged to inform the debtor about that and return such promissory note to the debtor at his request.

\subsection{Payment through Court Procedure}

If the creditor can not fully collect his claim from the debtor's account(s) following the specifications in the promissory note because the debtors accounts are empty or the assets on these accounts are not sufficient to cover the claims, payment then takes place under the provisions of Article 211 of the Distraint Law.

The commercial bank or FINA keeps promissory notes in the inquest register and according to the records in the inquest register it must transfer the funds as soon as they arrive at the debtor's account. It must be pointed out that according to Art. 183, section 7 of the Distraint Law the promissory note has the characteristics of a distraint document, which means that the creditor may and is entitled to request distraint against the debtors or guarantors of payers, if they have been specified in the promissory note beside the debtor issuer.

It is very important to investigate the circumstances around the debtor that may exist at the time when the request for initiation of distraint proceedings is being filed, as prescribed in Art. 4, section 7 of the Distraint Law, in order to establish the validity of seizure based on the given consent of the debtor and to justify the creditor's full right of claim.

Whether a thing or a right may be the subject of distraint, i.e. whether a distraint over a thing or a right is limited, is determined with respect to circumstances that have 
existed at the time when the distraint proposal has been filed, unless expressly determined otherwise by this Law.

Distraint can not be performed on: objects out of circulation; items specified by a special law; claims based on taxes and fees; objects, arms and equipment intended for defense; and movable property mentioned in Art. 128, section 1 of the Distraint Law.

Finally, distraint starts on the basis of the distraint proposal that moves into the phase of enforcement proceedings. The distraint proposal, in this case, is the promissory note; which irrefutably proves that the promissory note is an instrument of insurance that has the form of a formal legal distraint document.

\subsection{CONCLUSION}

Serious problems of guaranteeing the payment of monetary claims in Croatian economy - and in that connection endangerment of solvency - are being partly overcome by the use of promissory notes as payment security instrument

The elementary function of promissory notes is to guarantee and offer creditors safety in the collecting of their claims, whereas on the other hand there is the need and fear of every debtor that they could be manipulated by the creditor(s) after the claim has been collected.

The development of the institute of promissory note on the legal and economic basis in the past few years has not been negligible as compared to the viewpoint and the effects that have resulted from the use of promissory notes in the economy. Consequent implementation of the Distraint Law, the distribution of judicial powers and transfer of some of these powers to notaries public as arbitrators have transformed the institute of promissory note into a more significant factor, so that today it determines the debtorcreditor relations more successfully and more efficiently.

Promissory note has the characteristic of a valid writ of execution, so that in the moment of collecting the promissory note the authorized commercial bank or FINA as legal entities must treat the promissory note as a valid court ruling. Every debtor who has filled in a promissory note has no possibility to protect himself by court proceeding, because the creditor will coercively collect his claim from the account for which the debtor has previously given his consent. The creditor is entitled to charge the total claims, and if there is no money on these accounts, the promissory note is retained and the charging process can last as long as it takes for the creditor to collect his claims in full amount, in other words in the promissory note the institute of reservation has been founded as well. 


\section{LITERATURE}

1. Amon,F.:" Mjenica i zadužnica: i ostali načini podmirenja obveza: prijeboj, cesija i asignacija" (Bill of Exchange and Promissory Note: and Other Forms of Settling Debts: Compensation, Cession and Assignment) T.E.B., Zagreb, 2004

2. Amon,F.; Lulić,M.; Momčinović,H.; Vidović,A.: “Osiguranje plaćanja-mjenica, ček, akreditivi, zadužnica, fiducija" (Guarantee of Payment: bills of exchange, check, credentials, promissory note, trusteeship), RRIF Ekonomsko-pravna biblioteka, Zagreb, 2002

3. Gorenc,V.: "Osnove trgovačkog prava" (Essentials of Commercial Law), Gorenc \& al., Zagreb, 2001

4. Lulić,M.: "Kako koristiti zadužnicu?"(How to Use the Promissory Note), RRIF, no. 01/2004, pp. 199-203

5. Šimunec, N.: “Bjanko zadužnica-izdavanje i naplata” (Blank Promissory Note - Issuing and Charging), RRIF, no. 09/2004, pp. 60-70

6. Vidović,A.: "Nova zadužnica u prometu" (New Promissory Note in Circulation), Poslovni magazin, no. 03/2006, pp. 50-51

7. Zakon o obveznim odnosima (Law on Contractual and Other Relations), NN no. 53/91, no. $111 / 93$, no. $03 / 94$, no. $07 / 96$, no. $91 / 96$, no. $112 / 99$

8. Zakon o trgovačkim društvima (Company Law), NN no. 111/93, no. 34/99, no. 52/00, no. $118 / 03$.

9. Ovršni zakon (Distraint Law), NN no. 57/96, no. 88/05

10. www.legalis.hr/modules/newbb/viewtopic.php?topic_id2893=\&the forum

11. www.efzg.globalnet.hr/UserDocsImages/FINE/fin_FIT \% 20doc.dr.Jakovčević. pdf

12. www.rif.hr/0410/sadrbody.htm

13. www.poslovniforum.hr/the info/lit20b.asp 